Agr. Biol. Chem., 37 (10), 2245 2249, 1973

\title{
D-Ribulose Production by a Thiamine-requiring Corynebacterium Species ${ }^{\dagger}$
}

\author{
Mutsuo Shimamura, Juichi Yoshitake and Tomio Imai \\ Central Research Laboratory, Godo Shusei Co., Ltd., Matsudo, Chiba, Japan
}

Received May 2, 1973

\begin{abstract}
The effect of thiamine on the D-ribulose production from gluconate by a thiamine-requiring Corynebacterilum species was investigated. The D-ribulose production by the cells previously grown in a thiamine-deficient medium was higher than that by the cells grown in a thiaminerich medium and supplementation of the thiamine-deficient cells with thiamine resulted in a significant depression of the D-ribulose production. Gluconokinase and NADP-linked phosphogluconate dehydrogenase were detected in the cell-free extract of this organism. Oxidation and anaerobic dissimilation of D-ribose 5-phosphate by the cell-free extract of the thiaminedeficient cells are reduced and the addition of thiamine pyrophosphate to the extract enhanced the catabolic activities for D-ribose 5-phosphate. These results suggest that the accumulation of $\mathrm{D}$-ribulose by the thiamine-deficient cells is a consequence of a reduction of transketolase activity.
\end{abstract}

In the previous paper, ${ }^{1)}$ it was shown that a thiamine-requiring species of Corynebacterium was able to accumulate D-ribulose extracellularly when grown on gluconate as a sole carbon source. The accumulation of this ketopentose was depended on the thiamine concentration in the growth medium and the maximum accumulation was observed at the restricted concentration of thiamine for growth.

Accordingly, thiamine appeared to play a significant role in the accumulation of $\mathrm{D}$ ribulose.

The experiments described in this paper were undertaken to investigate the effect of a deficinecy of thiamine upon the accumulation of D-ribulose.

\section{MATERIALS AND METHODS}

Organism. Corynebacterium sp. No. 208, which was isolated by the authors, was employed for this study. This organism strictly requires thiamine for growth and is characterized by preferential utilization of gluconate as compared to other carbon sources. ${ }^{2}$ ?

$\dagger$ Gluconate Metabolism by a Thiamine-requiring Species of Corynebacterium. Part V. For Part IV, see Reference 1). This work was presented at the Annual Meeting of the Agricultural Chemical Society of Japan in Nagoya, April 2, 1968.
Cultural conditions. The organism was grown on a bouillon agar slant for $48 \mathrm{hr}$ at $30^{\circ} \mathrm{C}$ and a loopful of cells was inoculated to the growth medium. The growth medium consists of potassium gluconate, $6.0 \% ; \quad\left(\mathrm{NH}_{4}\right)_{2} \mathrm{SO}_{4}, 0.4 \% ; \mathrm{KH}_{2} \mathrm{PO}_{4} 0.1 \% ; \mathrm{MgSO}_{4}$. $7 \mathrm{H} \mathrm{O}, 0.05 \%$; and thiamine hydrochloride $(\mathrm{pH} 6.5)$. For the production of thiamine-rich and thiaminedeficient cells, thiamine hydrochloride was added to the medium at $100 \mu \mathrm{g}$ and $10 \mu \mathrm{g}$ per liter, respectively. Cultivation was carried out at $30^{\circ} \mathrm{C}$ on a reciprocal shaker operating at $210 \mathrm{rpm}$.

Preparation of washed cell suspension. After growth for $48 \mathrm{hr}$ in the media described above, the cells were harvested by centrifugation in the cold, washed 3 times with distilled water, and suspended in $0.05 \mathrm{M}$ phosphate buffer ( $\mathrm{pH} 7.0$ ).

Preparation of cell-free extracts. The washed cells were resuspended in $0.05 \mathrm{M}$ phosphate buffer (pH 7.0) or $0.05 \mathrm{M}$ tris-(hydroxymethyl)-aminomethane (Tris) buffer ( $\mathrm{pH} 7.5$ ) and disrupted by sonic oscillation for $60 \mathrm{~min}$ in a 200 watt, $10 \mathrm{kc}$ sonic generator. The disrupted cells suspension was centrifuged at $19,000 \mathrm{~g}$ for $40 \mathrm{~min}$ to remove cell debris. The supernatant fluid was then treated with charcoal and dialyzed against $0.05 \mathrm{M}$ phosphate buffer or $0.05 \mathrm{M}$ Tris buffer. The dialyzed solution was used as a cell-free extract of the organism throughout the experiments.

Enzyme assays. Phosphogluconate dehydrogenase activity was assayed spectrophotometrically by following the reduction of NADP at $340 \mathrm{~m} \mu$ with 6-phos- 
phogluconate as the substrate at $30^{\circ} \mathrm{C}$. The reaction mixture contained $0.5 \mu$ mole of NADP, $2 \mu$ moles of 6-phosphogluconate, $0.5 \mu$ mole of $\mathrm{MgCl}_{2} \cdot 6 \mathrm{H}_{2} \mathrm{O}$, $0.2 \mathrm{M}$ Tris buffer ( $\mathrm{pH} 7.5$ ), and the cell-free extract $(1.25 \mathrm{mg}$ of protein) in a total volume of $3.0 \mathrm{ml}$. Gluconokinase activity was measured by coupling the formation of 6-phosphogluconate to phosphogluconate dehydrogenase present in the extract and following reduction of NADP at $340 \mathrm{~m} / \mu$. The assay was carried out under the same conditions as for phosphogluconate dehydrogenase activity except that $1.0 \mu$ mole of ATP and $2.5 \mu$ moles of gluconate were substituted for 6-phosphogluconate. Transketolase activity was assayed according to the method of Brin ${ }^{3+}$ except that the temperature of incubation was $30^{\circ} \mathrm{C}$. This method is based on the conversion of D-ribose 5 -phosphate to hexose phosphate in the presence of thiamine pyrophosphate.

Analytical methods. D-Ribulose was determined in the cysteine-carbazole reaction as described previously. ${ }^{1}$ The concentration of protein in the cellfree extracts was determined by the method of Lowry et al. ${ }^{4}$ Oxygen uptake was determined by conventional Warburg manometric techniques at $30^{\circ} \mathrm{C}$.

Chemicals. ATP, NAD, NADP, 6-phospho-Dgluconate, D-ribose 5-phosphate and glyceraldehyde3-phosphate were products of Sigma Chemical Company. Thiamine hydrochloride and thiamine pyrophosphate were purchased from Tokyo Kasei Company.

\section{RESULTS}

Production of D-ribulose from gluconate by washed cell suspensions

As shown in Fig. 1, the maximum production of D-ribulose from gluconate under growing conditions occured at a thiamine hydrochloride concentration of $10 \mu \mathrm{g}$ per liter and further increase in the thiamine concentration caused a marked decrease in the production though an abundant cell growth was observed.

Therefore, the cells previously grown in media containing thiamine hydrochloride at $10 \mu \mathrm{g}$ and $100 \mu \mathrm{g}$ per liter were employed for the investigation of the effect of thiamine on the D-ribulose production. The cells thus obtained were refered to herein as thiaminedeficient and thiamine-rich cells, respectively.

The D-ribulose production from gluconate by the thiamine-deficient cells was higher than

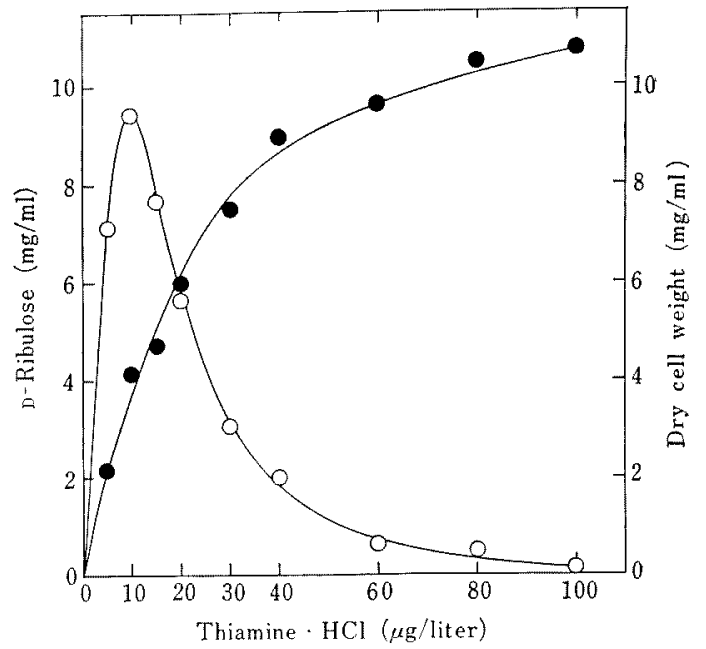

Frg. 1. Effect of Thiamine Concentration in the Growth Medium on D-Ribulose Accumulation and Cell Growth.

The basal growth medium was as described in Materials and Methods.

Cultivation was carried out at $30^{\circ} \mathrm{C}$ for $96 \mathrm{hr}$ on a reciprocal shaker operating at $210 \mathrm{rpm}$.

$\bigcirc-0$, D-ribulose; - - , dry cell weight.

that by the thiamine-rich cells as indicated in Table I. Moreover, supplementation of the

Table I. D-Ribulose Production from Gluconate by Washed Cell Suspension

The incubation mixture consisted of 1 mmole of potassium gluconate, $25 \mu$ moles of $\mathrm{MgSO}_{4} \cdot 7 \mathrm{H}_{2} \mathrm{O}$, $3 \mathrm{ml}$ of cell suspension ( $80 \mathrm{mg}$ of dry cell), and $4 \mathrm{ml}$ of $1 / 30 \mathrm{M}$ phosphate buffer at $\mathrm{pH} 7.0$ in a total volume of $10 \mathrm{ml}$.

Incubation was carried out at $30^{\circ} \mathrm{C}$ for $18 \mathrm{hr}$ on a reciprocal shaker operating at $210 \mathrm{rpm}$.

\begin{tabular}{|c|c|c|}
\hline \multirow[b]{2}{*}{$\begin{array}{l}\text { Addition to } \\
\text { incubation mixture }\end{array}$} & \multicolumn{2}{|c|}{ D-Ribulose produced (mmoles) } \\
\hline & $\begin{array}{l}\text { Thiamine- } \\
\text { deficient } \\
\text { cells }\end{array}$ & $\begin{array}{c}\text { Thiamine- } \\
\text { rich } \\
\text { cells }\end{array}$ \\
\hline None & 0.16 & 0.08 \\
\hline $\begin{array}{l}\text { Thiamine hydrochlori } \\
10 / \mathrm{g} \\
\text { Oxythiamine } 100 \% \mathrm{~g}\end{array}$ & $\begin{array}{l}0.03 \\
0.15\end{array}$ & $\begin{array}{l}0.05 \\
0.07\end{array}$ \\
\hline
\end{tabular}

thiamine-deficient cells with thiamine resulted in a significant depression of the production of D-ribulose.

These data suggest that the D-ribulose accumulation in this organism was introduced 
by the reduction of thiamine in the cells. Oxythiamine had no effect on the D-ribulose production by the thiamine-rich cells.

\section{Demonstration of gluconokinase and phospho-} gluconate dehydrogenase activities in cell-free extracts

Since D-ribulose 5-phosphate is an intermediate in the hexose monophosphate pathway, the presence of gluconokinase and phosphogluconate dehydrogenase in the cell-free extract prepared from the thiamine-deficient cells was examined. Figures 2 and 3 show that

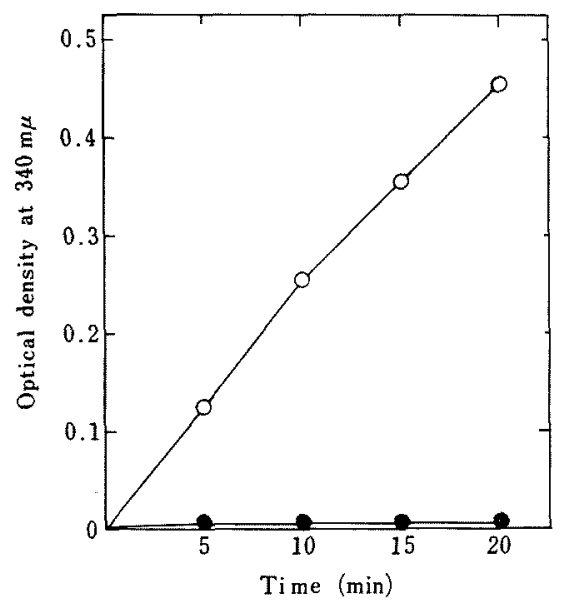

FIG. 2. Gluconokinase Activity in a Cell-free Extract.

Reaction mixture was as described in Materials and Methods.

$0-0$, ATP was added; $-\bullet$, no addition.

gluconokinase and NADP-dependent phosphogluconate dehydrogenase are present in the extract. As shown in Table II, gluconate oxidation by this extract occured in the presence of ATP. In addition, gluconate oxidation and pyruvate production by the washed cells suspension were found to be inhibited by the presence of $0.001 \mathrm{~m}$ monoiodoacetate. In Corynebacterium species, the hexose monophosphate pathway is believed to be the major route for the assimilation of gluconate. ${ }^{5}$

It appears from these results that in this organism gluconate is metabolized via the hexose monophosphate pathway after con-

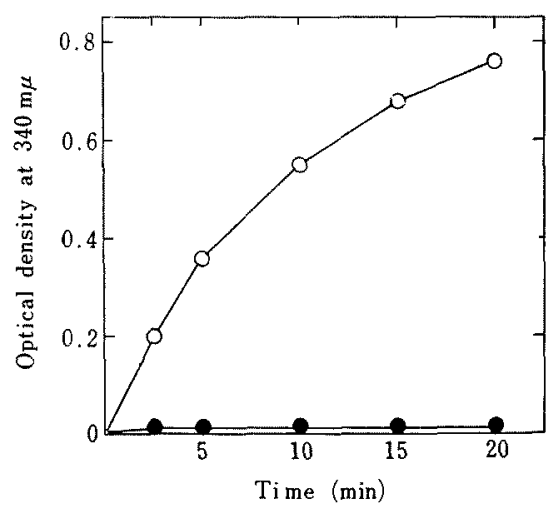

FIG. 3. Phosphogluconate Dehydrogenase Activity in a Cell-free Extract.

Reaction mixture was as described in Materials and Methods.

$O-O$, NADP; $-\bullet$, NAD.

Table II. EfFect of ATP on Gluconate OXIDATION BY A CELL-freE EXTRACT

The Warburg vessel contained $10 \mu$ moles of potassium gluconate, $10 \mu$ moles of $\mathrm{MgCl}_{2} \cdot 6 \mathrm{H}_{2} \mathrm{O}, 1 \mathrm{ml}$ of cell-free extract ( $12.5 \mathrm{mg}$ of protein), and $0.5 \mathrm{ml}$ of $1 / 10 \mathrm{M}$ phosphate buffer at $\mathrm{pH} 7.0$. The central well contained $0.2 \mathrm{ml}$ of $20 \% \mathrm{KOH}$. All vessels contained a total volume of $3.0 \mathrm{ml}$. Endogenous oxygen uptake was subtracted.

\begin{tabular}{lc}
\hline $\begin{array}{c}\text { Addition to } \\
\text { reaction mixture }\end{array}$ & $\begin{array}{c}\text { Oxygen uptake } \\
\left(\mu 1 \text { of } \mathrm{O}_{2} / \text { mg of protein } / \mathrm{hr}\right)\end{array}$ \\
\hline None & 0 \\
$\left.\mathrm{NAD}^{(1)}+\mathrm{NADP}^{a}\right)$ & 0 \\
$\mathrm{NAD}^{\mathrm{N}}+\mathrm{NADP}+\mathrm{ATP}^{b)}$ & 7.7 \\
\hline a) 1 mole. & \\
b) 5 moles. &
\end{tabular}

verting to 6-phosphogluconate.

Oxidation of D-ribose 5-phosphate by cell-free extracts

It has previously been shown that pyruvate was oxidized at a decreased rate by the suspension of the thiamine-deficient cells. ${ }^{6)}$

The oxidation of several substrates was examined using cell-free extracts prepared from the thiamine-deficient and thiamine-rich cells. As shown in Table III, the extract of the thiamine-deficient cells demonstrated poor oxidative ability for D-ribose 5-phosphate and pyruvate. 
Table III. Oxidation of Various Substrates by Cell-free Extracts

The Warburg vessel contained $10 \mu$ moles of substrate, $10 \mu$ moles of $\mathrm{MgCl}_{2} \cdot 6 \mathrm{H}_{2} \mathrm{O}, 5 \mu$ moles of ATP, $1 \mu$ mole of NAD, $1 \mu$ mole of NADP, $1.0 \mathrm{ml}$ of cellfree extract (12.5 mg of protein), and $0.5 \mathrm{ml}$ of $1 / 10 \mathrm{M}$ phosphate buffer at pH 7.0. The center well contained $0.2 \mathrm{ml}$ of $20 \% \mathrm{KOH}$. All vessels contained a total volume of $3.0 \mathrm{ml}$. Endogenous oxygen uptake was subtracted.

\begin{tabular}{lcc}
\hline \multirow{2}{*}{ Substrate } & \multicolumn{2}{c}{$\begin{array}{c}\text { Oxygen uptake } \\
\left(\mu \text { of } \mathrm{O}_{2} / \mathrm{mg} \text { of protein/hr) }\right.\end{array}$} \\
\cline { 2 - 3 } & $\begin{array}{c}\text { Thiamine- } \\
\text { deficient } \\
\text { cells }\end{array}$ & $\begin{array}{c}\text { Thiamine- } \\
\text { rich } \\
\text { cells }\end{array}$ \\
\hline Gluconate & 6.6 & 7.5 \\
6-Phospho-D-gluconate & 3.2 & 3.5 \\
D-Ribose 5-phosphate & 2.5 & 6.5 \\
Glyceraldehyde 3-phosphate & 3.4 & 3.3 \\
Pyruvate & 0.1 & 1.6 \\
\hline
\end{tabular}

Since the low rate of D-ribose 5-phosphate oxidation was presumed to be due to a decreased amount of thiamine in the extract, thiamine pyrophosphate was added to the extract to determine the effect of thiamine pyrophosphate on the D-ribose 5-phosphate oxidation. The data are presented in Fig. 4. The addition of thiamine pyrophosphate had some stimulating effect on the rate of D-ribose 5-phosphate oxidation in the thiamine-rich cells but a much greater effect was observed in the thiamine-deficient cells.

Dissimilation of D-ribose 5-phosphate by cellfree extracts

Further investigation was undertaken to determine the effect of thiamine on the dissimilation by the extracts according to the method of Brin. ${ }^{3\}}$ This method has been widely used to determine the transketolase activity in the erythrocytes and the various tissues of animals. In this method, transketolase activity is obtained by the measurements of the amount of pentose which is consumed and the amount of hexose which is formed during the incubation. Moreover, the levels of restoration of the enzyme activity by the addition of thiamine pyrophosphate,

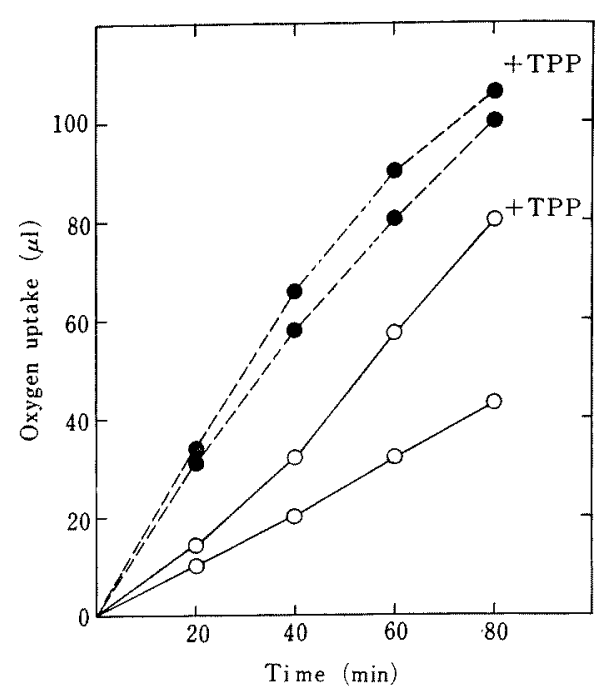

FIG. 4. Effect of Thiamine Pyrophosphate on DRibose 5-Phosphate Oxidation by Cell-free Extracts. The experimental conditions were the same as those in Table III. Endogenous oxygen uptake was subtracted.

$\mathrm{O}-\mathrm{O}$, thiamine-deficient cells; $---\bullet$, thiamine-rich cells.

+TPP, thiamine pyrophosphate was added to a final concentration of $3 \times 10^{-6} \mathrm{M}$.

which is called "TPP effect," can also be estimated. Therefore, this method appeared to be suitable to evaluate the effect of thiamine pyrophosphate on the dissimilation of Dribose 5-phosphate by the extract of thiaminedeficient cells. The results are given in Table IV. In the extract of the thiaminedeficient cells, both the consumption of pentose and the formation of hexose were significantly reduced. In addition, the remarkable restoration of the dissimilation of D-ribose 5-phosphate by the addition of thiamine pyrophosphate was observed in the extract of the thiamine-deficient cells.

\section{DISCUSSION}

Previous papers ${ }^{6}$ in this series have shown that a thiamine-requiring strain of Corynebacterium accumulated pyruvic acid extracellularly when grown under the restricted condition for thiamine and the accumulation of the keto acid was introduced by the depression 
Table IV. Dissimilation of D-Ribose 5-Phosphate by Cell-free Extracts

Assay procedure: The assay system in a total volume of $1.15 \mathrm{ml}$ consisted of $0.2 \mathrm{ml}$ of D-ribose 5phosphate (7.0 $\mathrm{mg}$ of ribose per $\mathrm{ml}$ ), $0.45 \mathrm{ml}$ of Brin buffer ( $\mathrm{pH} \mathrm{7.4),} \mathrm{and} 0.5 \mathrm{ml}$ of cell-free extract (12.5 $\mathrm{mg}$ of protein per $\mathrm{ml}$ ) with and without the addition of $0.45 \mathrm{ml}$ of thiamine pyrophosphate $(0.11 \mathrm{mg}$ of thiamine pyrophosphate per $\mathrm{ml}$ ). Incubation was carried out at $30^{\circ} \mathrm{C}$ for $60 \mathrm{~min}$.

Determination of pentose and hexose: After $60 \mathrm{~min} 6.0 \mathrm{ml}$ of $7.5 \%$ trichloroacetic acid was added to the reaction mixture. The protein free filtrate was used for the determination of the amount of the pentose consumed by the orcinol method with a 20 -min heating time at $670 \mathrm{~m} \mu$ and of the hexose formed by the anthrone method with a 10 -min heating time at $620 \mathrm{~m} \mu$.

\begin{tabular}{|c|c|c|c|c|c|c|}
\hline \multirow{2}{*}{ Cell-free extract } & \multicolumn{3}{|c|}{$\begin{array}{l}\text { Pentose consumption } \\
(/ \mathrm{g} / \mathrm{mg} \text { of protein } / \mathrm{hr})\end{array}$} & \multicolumn{3}{|c|}{$\begin{array}{l}\text { Hexose formation } \\
(\mu \mathrm{g} / \mathrm{mg} \text { of protein } / \mathrm{hr})\end{array}$} \\
\hline & $\begin{array}{l}\text { No } \\
\text { addition }\end{array}$ & $+\mathrm{TPP}^{a}$ & $\begin{array}{c}\text { TPP } \\
\text { effect }^{b} \text { ) } \\
(\%)\end{array}$ & $\begin{array}{l}\text { No } \\
\text { addition }\end{array}$ & $+\mathrm{TPP}$ & $\begin{array}{c}\text { TPP } \\
\text { effect } \\
(\%)\end{array}$ \\
\hline Thiamine-deficient cells & 90.4 & 246.0 & 172.1 & 40.0 & 168.2 & 302.5 \\
\hline Thiamine-rich cells & 270.0 & 287.1 & 6.3 & 181.9 & 205.9 & 13.2 \\
\hline
\end{tabular}

a) Thiamine pyrophosphate was added to the reaction mixture.

b) Values presented are percentage changed due to the presence of added thiamine pyrophosphate.

of the activity of pyruvate oxidation due to the decreasing the thiamine content of the cells.

As shown in Table I, the accumulation of D-ribulose by this organism was also found to be the result of the thiamine deficiency of the cells.

It is probable that the accumulation of D-ribulose by the thiamine-deficient cells, like that of pyruvic acid, is due to the decreased activity of thiamine-requiring enzymes involved in the catabolism of gluconate.

In the thiamine-deficient cells as shown in Fig. 4, D-ribose 5-phosphate was oxidized at a decreased rate and a marked increase in the oxidation rate was caused by the addition of thiamine pyrophosphate. Similarly, anaerobic dissimilation of D-ribose 5-phosphate in the thiamine-deficient cells was significantly enhanced by the addition of thiamine pyrophosphate (Table IV).

Thiamine pyrophosphate is known to function as a coenzyme for the enzymes involving decarboxylation and transketolation. It has been reported that the activity of transketolase in microorganisms depended on the thiamine content of the medium..$^{7,8)}$ Sasajima and Yoneda $^{9}$ reported that transketolase-lacking mutants of a Bacillus species accumulated D-ribose and D-ribulose 5-phosphate 3-epimerase-lacking mutants accumulated both D-ribose and D-ribulose.
Although further work is required to investigate the participation of some enzymes responsible for the catabolism of pentose phosphate to the accumulation of D-ribulose, it may be concluded from the present studies that the accumulation of D-ribulose by the thiaminedeficient cells is probably a consequence of a reduction of transketolase activity and that the reduced transketolase activity is not the result of a depletion of apoenzyme but a deficiency of coenzyme.

\section{REFERENCES}

1) M. Shimanura, J. Yoshitake and T. Imai, Agr. Biol. Chem., 35, 899 (1971).

2) M. Shimamura and J. Yoshitake, Nippon Nogeikagaku Kaishi, 44, 189 (1970).

3) M. Brin, "Methods in Enzymology," Vol. IX, ed. by W. A. Wood, Academic Press Inc., New York, N.Y., 1966, pp. 506 514.

4) O. H. Lowry, N. J. Rosenbrough, A. L. Farr and R. T. Randall, J. Biol. Chem., 193, 265 (1951).

5) A. C. Zagallo and C. H. Wang, J. Gen. Microbiol., 47, 347 (1967).

6) M. Shimamura and J, Yoshitake, Nippon Nogeikagaku Kaishi, 44, 195 (1970); idem, ibid., 44, 283 (1970).

7) 1. Witt and B. Neufang, Biochim. Biophys. Acta, 215, 323 (1970).

8) K. Takahashi, vitamins, 44, 313 (1971).

9) K. Sasajima and M. Yoneda, Agr. Biol. Chem., 35, 509 (1971). 